\title{
Pemberian Dedak Yang Difermentasi Dengan Em4 Sebagai Pakan Ayam Broiler
}

\author{
Najmah Ali ${ }^{1}$, Agustina $^{2}$, Dahniar ${ }^{3}$ \\ ${ }^{1,2}$ Program Studi Peternakan, Fakultas Peternakan dan Perikanan Universitas Sulawesi Barat, \\ ${ }^{3}$ Program Studi Agribisnis Fakultas Pertanian dan Kehutanan Universitas Sulawesi Barat \\ Email : najmahali31@gmail.com
}

\begin{abstract}
Abstrak
Penelitian ini bertujuan untuk mendapatkan formula yang tepat untuk broiler yang mendapatkan ransum berbahan dedak fermentasi untuk menghasilkan pertambahan berat badan (PBB) yang tinggi. Percobaan dilakukan dengan menggunakan 36 ekor DOC ayam broiler. Rancangan percobaan yang digunakan adalah Rancangan Acak Lengkap dengan 4 perlakuan dan 3 ulangan. Dalam setiap unit penelitian terdapat 3 ekor DOC. Perlakuan yang diterapkan adalah sebagai berikut $\mathrm{P} 0=$ $100 \%$ dedak fermentasi, $\mathrm{P} 1=90 \%$ dedak fermentasi $+10 \% \mathrm{BP} 11, \mathrm{P} 2=80 \%$ dedak fermentasi $+20 \% \mathrm{BP} 11, \mathrm{P} 3=70 \%$ dedak fermentasi $+30 \%$ BP 11. Penelitian dilakukan selama 4 minggu. Hasil penelitian menunjukkan bahwa level pemberian dedak fermentasi EM 4 ( $\mathrm{P} 0, \mathrm{P} 1, \mathrm{P} 3)$ sangat nyata menghasilkan pertambahan berat badan yang lebih tinggi dibandingkan dengan P0. Pemberian dedak fermentasi tidak berpengaruh nyata terhadap tingkat konsumsi dan konversi ransum, tetapi terdapat perbedaan pada tingkat konsumsi yaitu pada $\mathrm{P} 3=70 \%$ dedak fermentasi $+30 \%$ BP11 memperlihatkan tingkat konsumsi ransum dan konversi ransum lebih tinggi dari perlakuan lainnya (P0, P1, P2). Berdasarkan penelitian dapat disimpulkan bahwa pemberian dedak fermentasi dengan EM4 sebagai pakan ayam broiler dapat diberikan hingga $70 \%$.
\end{abstract}

Keywords: dedak, fermentasi, EM4, broiler

\section{Pendahuluan}

Kebutuhan akan bahan pangan misalnya ketersedian daging dari tahun ke tahun mengalami peningkatan seiring dengan semakin meningkatnya jumlah penduduk, tingkat pendidikan dan kesadaran masyarakat akan peranan zat-zat makanan khususnya protein bagi bagi kehidupan. Selain itu industri pengolahan produk asal ternak juga berkembang seiring dengan berkembangnya daerah perkotaan. Salah satu komoditas peternakan yang dapat memberikan kontribusi yang besar dalam penyediaan protein hewani adalah ayam ras pedaging (broiler). Ayam broiler atau disebut juga ras pedaging adalah jenis ras unggulan hasil persilangan dari bangsa-bangsa ayam yang memiliki produktifitas tinggi, terutama dalam produksi daging (Fischer, et al, 2014).

Salah satu faktor penentu keberhasilan suatu peternakan adalah faktor pakan, disamping faktor genetik dan tatalaksana pemeliharaan. Biaya pakan dalam suatu usaha peternakan merupakan komponen terbesar dari total biaya produksi yang harus dikeluarkan peternak selama proses produksi yaitu sekitar 60-70\%. Untuk memenuhi kebutuhan nutrisi yang lengkap diperlukan pemberian pakan yang beragam dan berkualitas, baik pakan yang berasal dari tumbuhan maupun pakan asal hewan. Untuk mengatasi kendala tersebut dibutuhkan inovasi-inovasi baru dalam penyediaan pakan yang berkualitas, salah satu alternatif adalah penggunaan dedak fermentasi dalam formulasi ransum broiler.Dedak padi (rice bran) merupakan hasil samping limbah pertanian yang dapat dimanfaatkan sebagai sumber energi pada pakan ternak dengan kandungan serat kasar 26-27 \%. Masalah utama dari penggunaan dedak padi sebagai pakan ternak adalah rendahnya kandungan protein kasar dan tingginya kandungan serat kasar (Gunawan et al, 2014). Cara untuk meningkatkan nilai nutrisi dan kecernaan dedak padi serta aman penggunaannya adalah dengan cara biologis yaitu dengan teknik fermentasi.

Peningkatan yang terjadi pada dedak padi fermentasi adalah meningkatnya kandungan protein kasar. Fermentasi merupakan salah satu teknologi pengolahan bahan pakan secara biologis yang melibatkan aktifitas mikroorganisme guna memperbaiki gizi bahan berkualitas rendah. Biasa bahan produk fermentasi relatif bisa bertahan lama. Fermentasi dapat meningkatkan kualitas nutrisi bahan pakan, karena proses fermentasi terjadi perubahan kimiawi senyawa-senyawa organic (karbohidrat, lemak, protein, serat kasar dan bahan organik lain baik dalam keadaan aerob maupun anaerob, melalui kerja enzim yang dihasilkan mikroba. Menurut Sukaryana et al (2011), proses fermentasi dapat meminimalkan pengaruh antinutrisi dan meningkatkan kecernaan bahan pakan dengan kandungan serat kasar tinggi yang terdapat pada dedakpadi. Metode fermentasi yang dapat digunakan untuk menurunkan serat kasar pada dedak padi adalah fermentasi dengan menggunakan probiotik cair EM4 yang mengandung sebagian besar bakteri fotosintetik (Rhodopseumonas spp), bakteri asam laktat (Lactobacillus spp), yeast (Saccharomyces spp) yang menguntungkan bagi 
pertumbuhan produksi ternak. Atas dasar pertimbangan tersebut maka dilakukan penelitian tentang pengaruh penggunaan dedak fermentasi dengan EM4 terhadap performans ayam broiler.

\section{Bahan Dan Metode}

Percobaan dilakukan dengan menggunakan 36 ekor DOC ayam broiler dan ditempatkan dalam kandang metabolis yang dilengkapi dengan tempat pakan dan tempat minum. Rancangan percobaan yang digunakan adalah Rancangan Acak lengkap dengan 4 perlakuan dan 3 ulangan sehingga terdapat 12 unit penelitian, setiap unit penelitian terdapat 3 ekpr ayam Perlakuan yang diterapkan adalah sebagai berikut :

P0 $=100 \%$ dedak fermentasi,

$\mathrm{P} 1=90 \%$ dedak fermentasi $+10 \%$ BP 11 ,

$\mathrm{P} 2=80 \%$ dedak fermentasi $+20 \%$ BP 11 ,

$\mathrm{P} 3=70 \%$ dedak fermentasi $+30 \%$ BP 11 .

Pembuatan dedak fermentasi dilakukan dengan menggunakan $20 \mathrm{~kg}$ dedak halus, 60 gram gula pasir, 60 gram EM-4 dan 10 liter air, selanjutnya diperam selama (fermentasi) selama 5 hari. Hasil fermentasi dibuka dan diangin-anginkan kemudian diberikan pada ayam broiler sesuai dengan perlakuan yang diterapkan.

Ransum penelitian terdiri dari dedak fermentasi dan pakan komplit BP11. Komposisi ransum BP11 dapat dilihat pada tabel 1 .

Tabel 1. Kandungan Nutrisi Ransum Jadi BP11 Untuk Ayam Broiler Pada Fase starter

\begin{tabular}{|l|l|}
\hline Zat Nutrisi & Kandungan (\%) \\
\hline Kadar air & 13,0 \\
Protein & $21,0-23,0$ \\
Lemak & 5,0 \\
Serat & 5,0 \\
Abu & 7,0 \\
Kalsium & 0,90 \\
Phospor & 0,60 \\
\hline
\end{tabular}

Percobaan dilakukan selama 5 minggu terdiri dari 5 hari masa pendahuluan dan 4 minggu masa pengambilan data. Pemberian pakan perlakuan dilakukan 2 kali setiap hari, air minum diberikan secara adlibitum. Parameter yang diukur meliputi konsumsi pakan, pertambahan berat badan konversi ransum. Semua data yang diperoleh dianalisis secara statistik menggunakan analisis ragam (Steel dan Torrie, 1981).

a. Konsumsi ransum, diukur dengan menimbang selisih antara ransum yang diberikan dengan ransum yang tersisa setiap harinya.

Konsumsi ransum $=$ Ransum yang diberi - Ransum sisa.

b. Pertambahan berat badan, dihitung berdasarkan berat badan akhir dikurangi berat badan awal kemudian dibagi dengan lama pemeliharaan

Pertambahan Berat Badan $=\underline{\text { Berat badan akhir }(\mathrm{g}) \text {-Berat badan awal }(\mathrm{g})}$

Lama pemeliharaan (hari) c. Konversi ransum, dihitung berdasarkan perbandingan antara ransum yang dikonsumsi dengan pertambahan berat badan.

Konversi ransum $=\sum$ pakan yang diberikan- $\sum$ pakan sisa $\sum$ pertambahan berat badan

\section{Hasil Dan Pembahasan}

\section{Pertambahan Berat Badan}

Pertambahan berat badan ayam broiler percobaan tertera pada tabel 2. Pemberian pakan dedak fermentasi berpengaruh sangat nyata terhadap pertambahan berat badan ayam broiler. Peningkatan Pertambahan bobot badan tersebut sebagai akibat dari meningkatnya konsumsi protein kasar dan perbaikan kualitas ransum terkonsumsi.

Tabel 2. Rata-Rata Pertambahan Berat Badan Ayam Broiler Dengan Pemberian DedakFermentasi(gr/ekor/hari)

\begin{tabular}{|l|l|l|}
\hline Perlakuan & Rata-Rata & NP.BNJ $\alpha 0,01$ \\
\hline PO & $7,00^{\mathrm{a}}$ & \\
P1 & $12,63^{\mathrm{b}}$ & 1,012 \\
P2 & $19,11^{\mathrm{c}}$ & \\
P3 & $126,58^{\mathrm{d}}$ & \\
\hline
\end{tabular}

Ket : Angka yang dikuti oleh huruf yang berbeda berarti berbeda nyata pada taraf uji $\mathrm{BNJ} \alpha 0,01$.

Pemberian dedak fermentasi EM4 (P3) menghasilkan pertambahan bobot badan yang lebih tinggi dibanding dengan pemberian $100 \%$ dedak fermentasi (P0), 90\% dedak fermenntasi $+10 \%$ BP11 (P1) dan $80 \%$ dedak fermentasi + 20\%BP11. Hal ini disebabkab karena kualitas pakan semakin baik setelah difermentasi. Hal ini sejalan dengan yang dikemukakan oleh Wahyu (2004) menyatakan bahwa pertambahan berat pada ternak secara keseluruhan berbanding lurus dengan konsumsinya. Semakin tinggi konsumsi akan diiringi dengan pertambahan berat badan yang juga meningkat. Untuk mencapai tingkat pertumbuhan optimal sesuai dengan potensi genetik, diperlukan ransum yang mengandung unsur gizi secara kualitatif dan kuantitatif, dengan demikian ada hubungan kecepatan pertumbuhan dengan konsumsi ransum. Kualitas ransum dipengaruhi oleh perlakuan bioteknologi fermentasi pada prinsipnya dapat menaikkan kualitas bahan berserat tinggi, baik oleh adanya penyederhanaan fraksi serat kasar menjadi komponen dasar energi tersedia maupun protein sel tunggal yang berasal dari multiplikasi biomassa sel mikroorganisme. Salah satu bioteknologi fermentasi yang dapat digunakan ialah bioteknologi "Effective Microorganisms" (EM4) (Telew, C et al, 2013).

\section{Konsumsi Ransum}

Konsumsi ransum pada ayam broiler percobaan tertera pada gambar 1 dan lampiran 3a. Pemberian dedak fermentasi tidak berpengaruh nyata $(\mathrm{P}<0,05)$ terhadap konsumsi ransum ayam broiler. Namun apabila konsumsi ransum ditampilkan dalam bentuk histogram, maka terlihat pemberian dedak fermentasi pada P3 (70\% dedak fermentasi $+30 \%$ BP11) menaikkan konsumsi ransum. Hal 
ini disebabkan karena palatabilitas atau daya suka terhadap ransum dengan komposisi $70 \%$ dedak fermentasi dan 30\% BP11.

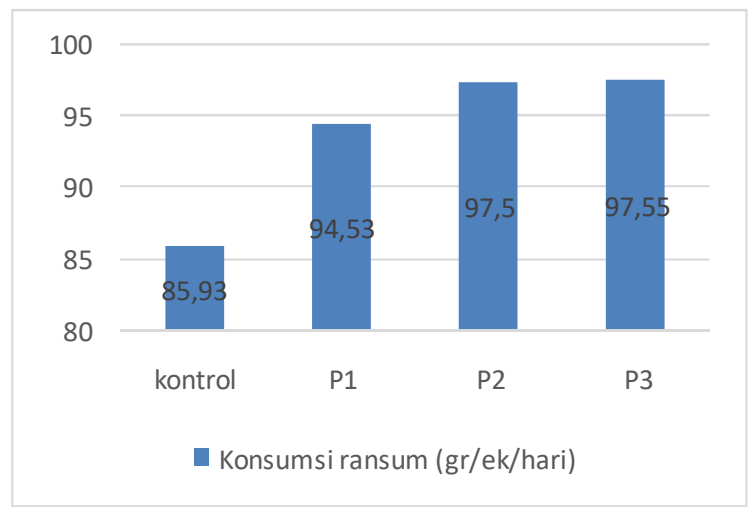

Gambar 1. Histogram Rata-Rata Konsumsi Ransum (gr/ek/hari)

Faktor lain yang mempengaruhi konsumsi ransum broiler diantaranya adalah besar dan bangsa ayam, luas kandang, tingkat energi dan protein dan protein. Wahyu (2004) menyatakan bahwa faktor yang dapat mempengaruhi konsumsi adalah palatabilitas. Palatabilitas dipengaruhi oleh bau, rasa, tekstur dan warna pakan yang diberikan. Palatabilitas merupakan sifat performans dari bahan-bahan sebagai akibat dari keadaan fisik dan kimiawi yang dimiliki bahan pakan tersebut. Lebih lanjut dikatakan bahwa perbedaan konsumsi pakan dipengaruhi oleh umur,kualitas dan kuantitas ransum, palatabiltas ransum dan pengolahannya. Konsumsi ransum yang diperoleh pada penelitian ini tertinggi pada P3 dengan pemberian dedak fermentasi $70 \%+30 \%$ BP11. Perlakuan 3 (P3) adalah perlakuan dengan tingkat pemberian dedak fermentasi yang paling rendah tarafnya dan sekaligus menjadi perlakuan yang memberikan pengaruh yang paling baik, dan ada kecenderungan semakin tinggi pemberian dedak fermentasi ke dalam ransum maka konsumsi ransum cenderung menurun, hal ini berkaitan dengan yang dikemukakan oleh Kartasudjana dan Suprijatna (2006) bahwa ayam akan mengkonsumsi ransum untuk memenuhi kebutuhan energinya, sebelum kebutuhan energinya terpenuhi ayam akan terus makan. Jika ayam diberi pakan dengan kandungan energi rendah maka ayam akan makan lebih banyak. Semakin baik mutu pakan yang diberikan semakin kecil pula jumlah konsumsi pakan yang dikonsumsi oleh ternak.

\section{Konversi Ransum}

Hasil analisis sidik ragam menunjukkan bahwa penggunaan dedak fermentasi dengan EM4 tidak berpengaruh nyata $(\mathrm{P}<0,05)$ terhadap konversi ransum ayam broiler fase starter (tabel lampiran 3b). Berikut diagram rataan konversi ransum ayam broiler fase starter.
Berdasarkan rataan konversi ransum ayam broiler diatas menunjukkan bahwa perlakukan P3 $(3,66)$ memberikan hasil yang lebih baik dibandingkan dengan $\mathrm{P} 0$ $(4,10)$, P $(5,11)$ dan P1 $(7,47)$.

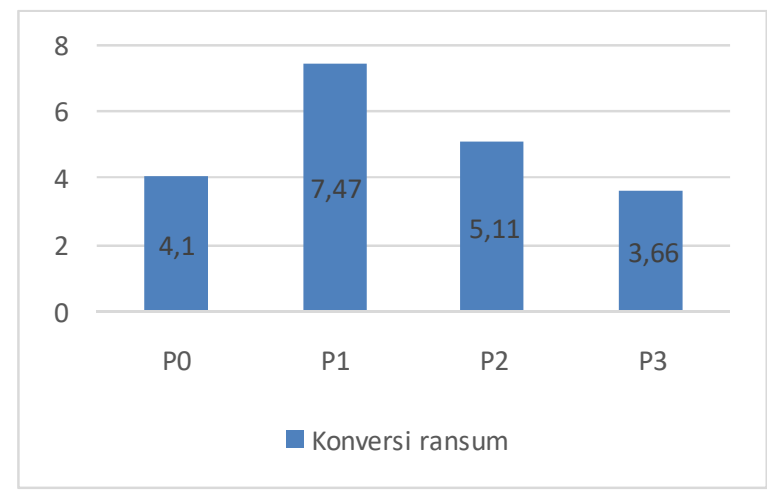

Gambar 2. Histogram Rata-Rata Konversi Ransum (gr/ek/hari)

Analisis sidik ragam menunjukkan bahwa penggunaan dedak fermentasi dengan EM4 tidak memberikan pengaruh yang nyata terhadap konversi pakan (tabel 3a dan 3b). perlakuan yang memiliki nilai konversi paling baik secara perhitungan adalah perlakuan P3 $(3,66)$, walaupun secara statistik tidak nyata $(\mathrm{P}>0,05)$. Perlakuan yang paling buruk nilai konversinya adalah P1 $(7,47)$. Hal tersebut menunjukkan bahwa ayam pada perlakuan $\mathrm{P} 3$ lebih efesien dalam memanfaatkan ransum yang dikonsumsi untuk setiap kenaikan bobot badannya dibandingkan perlakuan P1. Pada P3 (70\% dedak fermentasi $+30 \%$ BP11), ransum memiliki kualitas yang lebih baik jika hanya menggunakan $70 \%$ dedak fermentasi dibandingkan perlakuan P1 yang menggunakan 90\% dedak fermentasi dan P2 yang menggunakan $80 \%$ dedak fermentasi. Kandungan protein pada BP 11 sama, akan tetapi dengan bertambahnya persentase dedak dalam penyusunan ransum akan menyebabkan meningkatnya kandungan serat kasar ransum.

Hasil perhitungan konversi ransum dengan nilai terkecil juga menggambarkan tingkat efesiensi ransum yang paling baik yaitu pada P3 (70\% dedak fermentasi $+30 \%$ BP11), hal ini sejalan dengan yang dikemukakan oleh Lacy dan Veast (2000), bahwa konversi ransum digunakan untuk mengukur produktivitas ternak dan didefinisikan sebagai rasio antara konsumsi ransum dengan pertambahan bobot badan (PBB) yang diperoleh selama kurun waktu tertentu. Efisiensi penggunaan ransum dapat dilihat dari nilai konversi ransum yang diberikan. Konversi ransum yang semakin kecil merupakan indikator semakin tingginya efisiensi ransum. Sebaliknya, konversi ransum yang semakin besar merupakan indikator semakin rendahnya efisiensi ransum.

\section{Kesimpulan}

Penggunaan dedak fermentasi dengan EM4 berpengaruh sangat nyata terhadap pertambahan bobot badan tetapi tidak berpengaruh terhadap konsumsi dan 
konversi pakan. Dedak fermentasi dengan EM4 dapat diberikan pada ayam broiler hingga $70 \%$.

\section{Daftar Pustaka}

Fischer, T, Byerlee, D and Edmeades, G. 2014. Crop yields and global food security. ACIAR Monograph No. 158. Australian Centre for International Agricultural Research: Canberra. xxii +634 pp.

Gunawan, Widyobroto,B.P, Setioko A.R, Muladno. 2014. Teknologi Pakan Mendukung Pengembangan Sapi Potong di Indonesia. Gadjah Mada University Press. Yogyakarta.

Hartadi, H., Reksohadiprodjo, S., Tillman, A.D. 2017. Indonesian Feed Composition Tables. $6^{\text {th }}$ Edition, Gadjah Mada University Press, Yogyakarta.

Lacy, M. \& L. R. Veast. 2000. Improving Feed Conversion in Broiler : A Guide for Growers. Springer Science and Business Media Inc., New York.

NRC. 2016. Nutrient Requirement of Beef Cattle, Eighth Revised Edition, National Academy of Sciences, Washington DC.

Suprijatna, E., U. Atmomarsono dan R. Kartasudjana. 2005. Ilmu Dasar Ternak Unggas. Penebar Swadaya, Jakarta.

Sukaryana, Y.U, Atmomarsono, V.D, Yunianto, E. Supriyatna. 2011. Peningkatan Nilai Kecernaan Protein Kasar dan Lemak Kasar Produk Fermentasi Campuran Bungkil Inti Sawit dan dedak Padi pada Broiler. JITP, 1(3) : 167-172.

Telew, C, Kereh, V.G, Untu, I.M dan Rembet B.W. 2013. Pengayaan Nilai Nutritif Sekam Padi berbasis Bioteknologi "Effective Microorganism" (EM4) Sebagai bahan pakan Organik.Jurnal Zootek (“Zootek"Journal), Vol.32 No. 5

Wahyu, J. 2004. Ilmu Nutrisi Unggas. Gadjah Mada University Press, Yogyakarta. 